\title{
Situs inversus totalis with perforated duodenal ulcer: a case report
}

\author{
Mohammad Tayeb ${ }^{1 *}$, Faiz Mohammad Khan ${ }^{1}$ and Fozia Rauf ${ }^{2}$
}

\begin{abstract}
Introduction: Situs inversus is an uncommon anomaly. Situs inversus viscerum can be either total or partial. Total situs inversus, also termed as mirror image dextrocardia, is characterized by a heart on the right side of the midline while the liver and the gall bladder are on the left side. Patients are usually asymptomatic and have a normal lifespan. The exact etiology is unknown but an autosomal recessive mode of inheritance has been speculated. The first case of perforated duodenal ulcer with situs inversus was reported in 1986; here, we report the second case of this nature in the medical literature.

Case presentation: A 22-year-old Pakistani man presented with severe epigastric and left hypochondrial pain. Examination and investigations (chest X-ray and ultrasonography) confirm peritonitis in a case of situs inversus totalis. On exploratory laparotomy, a diagnosis of situs inversus totalis with perforated duodenal ulcer was confirmed. Graham's patch closure of the duodenal ulcer was performed with absorbable sutures, and a thorough peritoneal lavage was also performed; an incidental appendectomy was also performed to avoid further diagnostic problems. Our patient had an uneventful recovery.

Conclusions: A diagnostic dilemma arises whenever abdominal pathology occurs in patients with situs inversus. Although an uncommon anomaly, to choose a proper surgical incision site for abdominal exploration pre-operative recognition of the condition is important.
\end{abstract}

\section{Introduction}

Situs inversus, first described by Aristotle in animals and Fabricius in humans [1], is an uncommon anomaly with an incidence varying from one in 4,000 to one in 20,000 live births [2]. Situs inversus viscerum can be either total or partial. Total situs inversus, also termed as mirror image dextrocardia, is characterized by a heart on the right side of the midline while the liver and the gall bladder are on the left side. Patients are usually asymptomatic and have a normal lifespan. The exact etiology is unknown but an autosomal recessive mode of inheritance has been speculated [3]. However, situs inversus abdominus, characterized by 'mirror image' of the normal bowel, is caused by a clockwise rotation of the viscera during early embryonic life [4]. Very few cases of situs inversus totalis have been described in the literature.

\footnotetext{
* Correspondence: drmtayeb@yahoo.com

'Department of Surgery, Peshawar Medical College, Peshawar, Pakistan Full list of author information is available at the end of the article
}

\section{Case presentation}

A 22-year-old Pakistani man, who was a smoker and hashish user, was admitted to the emergency department of our hospital with sudden onset of severe epigastric and left hypochondrial pain for last 12 hours. He also complained of nausea and vomiting. He had a history of recurrent episodes of epigastric and left hypochondrial pain. A physical examination revealed a pulse rate of 105 beats/minute, blood pressure of 110/70 $\mathrm{mmHg}$, and he was afebrile. Examination of his abdomen revealed guarding and rigidity, especially in the epigastrium and left hypochondrium. The laboratory results showed a serum hemoglobin level of $11 \mathrm{~g} \%$ and a white cell count of $16,000 \mathrm{cmm}$ with neutrophilia. His serum amylase level was at the upper limit of normal, but other biochemical test results were essentially normal. Results of an X-ray of the chest taken in the erect position showed dextrocardia, a fundic gas shadow under the right dome of diaphragm and a liver shadow on the left side. There was free gas under the left dome of the diaphragm (Figure 1). A clinical diagnosis of perforated
C Biomed Central

C 2011 Tayeb et al; licensee BioMed Central Ltd. This is an Open Access article distributed under the terms of the Creative Commons Attribution License (http://creativecommons.org/licenses/by/2.0), which permits unrestricted use, distribution, and reproduction in any medium, provided the original work is properly cited. 
patient had an uneventful recovery. Post-operatively he was counseled about cessation of smoking and hashish and was sent home on omeprazole therapy.

\section{Discussion}

Situs inversus abdominus is an uncommon anomaly with an incidence varying from one in 4,000 to one in 20,000 live births [2]. Situs inversus usually remains undiagnosed, as exemplified by the present case, unless it is diagnosed incidentally while investigating another associated ailment. A diagnostic dilemma arises whenever pathology occurs in the unusual located abdominal viscera. To choose a proper surgical incision for abdominal exploration, pre-operative recognition of the condition is important. In our case the diagnosis was made pre-operatively and an exploratory laparotomy was performed with an upper midline incision.

Certain congenital anomalies such as polysplenia, asplenia or Kartagener's syndrome are known to occur in such patients $[5,6]$. However, our patient did not have any of these abnormalities.

Various modalities such as electrocardiograms, radiographic studies, computed tomography $(\mathrm{CT})$ scans with oral and intravenous contrast, ultrasound, and barium studies can be used to diagnose situs inversus $[7,8]$. In our case, we diagnosed the condition by a chest radiograph and abdominal ultrasonography.

There have been isolated reports of situs inversus associated with peptic ulcer [9], ulcer perforation [10], amoebic liver abscess [11], acute cholecystitis [12], cholelithiasis [13,14], acute appendicitis [15], and intestinal obstruction [16]. To the best of our knowledge, this is only the second report in the literature of a patient with situs inversus totalis presenting with perforated duodenal ulcer (Gandhi et al. reported the first case of perforated duodenal ulcer with situs inversus in 1986 [10]).

\section{Conclusions}

A diagnostic dilemma arises whenever abdominal pathology occurs in patients with situs inversus. Although an uncommon anomaly, to choose a proper surgical incision site for abdominal exploration pre-operative recognition of the condition is important.

\section{Consent}

Written informed consent was obtained from the patient for publication of this case report and any accompanying images. A copy of the written consent is available for review by the Editor-in-Chief of this journal.

\section{Author details}

${ }^{1}$ Department of Surgery, Peshawar Medical College, Peshawar, Pakistan. ${ }^{2}$ Department of Pathology, Peshawar Medical College, Peshawar, Pakistan. omy was also performed to avoid further diagnostic problems and the abdomen was closed in layers. Our 


\section{Authors' contributions}

MT performed the surgery and wrote the main part of the manuscript. FMK and FR reviewed the manuscript and made valuable changes.

\section{Competing interests}

The authors declare that they have no competing interests.

Received: 29 September 2010 Accepted: 3 July 2011

Published: 3 July 2011

\section{References}

1. Blegen HM: Surgery in situs inversus. Ann Surg 1949, 129:244-259.

2. Budhiraja S, Singh G, Miglani HP, Mitra SK: Neonatal intestinal obstruction with isolated levocardia. J Pediatr Surg 2000, 35:1115-1116.

3. Djohan RS, Rodriguez HE, Wiesman IM, Unti JA, Podbielski FJ: Laparoscopic cholecystectomy and appendectomy in situs inversus totalis. JSLS 2000, 4:251-254.

4. Van Steensel CJ, Wereldsma JC: Acute appendicitis in complete situs inversus. Neth J Surg 1985, 37:117-118.

5. Almy MA, Volk FH, Graney CM: Situs inversus of stomach. Radiology 1953, 61:376-378.

6. Willis JH: The Heart. 5 edition. New York: McGraw Hill Book Company; 1982, 817.

7. Nelson MJ, Pesola GR: Left lower quadrant pain of unusual cause. J Emerg Med 2001, 20:241-245.

8. Ratani RS, Halter JO, Wang WY, Yang DC: Role of CT in left-sided acute appendicitis: case report. Abdom Imaging 2002, 27:18-19.

9. Zaporozhets VK, Chupryna W, Vasilenko NJ, Mal'ko VI: lazvennaia bolelzn' zheludka pri polnoi inversii vnufrennikh organov [in Russian]. Klin Med (Mosk) 1980, 58:95-96.

10. Gandhi DM, Warty PP, Pinto AC, Shetty SV: Perforated DU with dextrocardia and situs inversus. J Postgrad Med 1986, 32:45-46.

11. Ansari ZA, Skaria J, Gopai MS, Vaish SK, Rai AN: Situs inversus with amoebic liver abscess. J Trop Med Hyg 1973, 76:169-170.

12. Heimann T, Sialer A: Acute cholecystitis with situs inversus. NY State J Med 1979, 79:253-254.

13. McFarland SB: Situs inversus with cholelithiasis. A case report. J Tenn Med Assoc 1989, 82:69-70.

14. Pathak KA, Khanna R, Khanna N: Situs inversus with cholelithiasis. J Postgrad Med 1995, 41:45-46.

15. Ucar AE, Ergul E, Aydin R, Ozgun YM, Korukluoglu B: Left-sided acute appendicitis with situs inversus totalis. Internet I Surg 2007, 12:2.

16. Ruben GD, Templeton JM Jr, Ziegier MM: Situs inversus. The complex inducing neonatal intestinal obstruction. J Ped Surg 1983, 18:751-756.

doi:10.1186/1752-1947-5-279

Cite this article as: Tayeb et al: Situs inversus totalis with perforated

duodenal ulcer: a case report. Journal of Medical Case Reports 2011 5:279.

\section{Submit your next manuscript to BioMed Central and take full advantage of:}

- Convenient online submission

- Thorough peer review

- No space constraints or color figure charges

- Immediate publication on acceptance

- Inclusion in PubMed, CAS, Scopus and Google Scholar

- Research which is freely available for redistribution 